\title{
Perception of nurses who perform rapid tests in Health Centers
}

\author{
Percepção de enfermeiros executores de teste rápido em Unidades Básicas de Saúde \\ Percepción de enfermeros ejecutores de prueba rápida en Centros de Salud
}

\section{Willamis José Araújo', Evelyn Maria Braga Quirino", Clarissa Mourão Pinho", Maria Sandra Andrade',"I \\ I Instituto de Medicina Integrada Professor Fernando Figueira, Multiprofessional Residence in Collective Health. Recife, Pernambuco, Brasil. \\ " Universidade Federal de Pernambuco, Postgraduate Program in Nursing. Recife, Pernambuco, Brasil.}

How to cite this article:

Araújo WJ, Quirino EMB, Pinho CM, Andrade MS. Perception of nurses who perform rapid tests in Health Centers.

Rev Bras Enferm [Internet]. 2018;71(Suppl 1):631-6. [Thematic Issue: Contributions and challenges of nursing practices in collective health] DOI: http://dx.doi.org/10.1590/0034-7167-2017-0298

Submission: 07-25-2017 Approval: 11-02-2017

\begin{abstract}
Objective: Learn about the perception of health professionals who perform rapid tests in Health Centers (HCs). Method: This is a descriptive and qualitative study conducted in nine HCs in Recife. Data were collected through individual interviews and evaluated using Bardin's content analysis, in its thematic category. Results: Challenges were observed in rapid tests related to the supply of products, physical structure, training for pre- and post-test counseling, and the need for improvements in permanent education actions. Final considerations: These issues can be resolved with management improvements, systematization of permanent education activities, and definition of care flows that enable early diagnosis. Besides the diagnosis, care lines should be created for people living with HIV and AIDS who use the HCs for early health care process.
\end{abstract}

Descriptors: Delivery of Health Care; HIV; AIDS; Primary Health Care; Nursing.

\section{RESUMO}

Objetivo: conhecer a percepção de profissionais de saúde executores de teste rápido em Unidades Básicas de Saúde (UBS). Método: estudo descritivo e qualitativo realizado em nove UBS em Recife. Os dados foram coletados através de entrevista individual e avaliados por meio da análise de conteúdo de Bardin, em sua modalidade temática. Resultados: verificam-se fragilidades para realização dos testes rápidos, relacionadas à logística de materiais e insumos, estrutura física, capacitação para realização do aconselhamento pré e pós-teste, e a necessidade de melhorias nas ações de educação permanente. Considerações finais: essas dificuldades podem ser equacionadas com a melhoria da gestão, sistematização das atividades de educação permanente e definição de fluxos de atendimento que possibilitem o diagnóstico precoce. Além do diagnóstico, é necessário estabelecer linhas de cuidado para pessoas vivendo com HIV e aids que tenham como início do processo de assistência à saúde as UBS.

Descritores: Assistência à Saúde; HIV; Aids; Atenção Primária à Saúde; Enfermagem.

\section{RESUMEN}

Objetivo: conocer la percepción de profesionales de salud ejecutores de prueba rápida en Centros de Salud (CS). Método: estudio descriptivo y cualitativo realizado en nueve UBS en Recife. Los datos fueron recogidos a través de encuesta individual y evaluados por medio del análisis de contenido de Bardin, en su modalidad temática. Resultados: se certifican fragilidades para la realización de las pruebas rápidas, relacionadas a la logística de materiales e insumos, estructura física, capacitación para la realización del asesoramiento pre y pos-prueba, y la necesidad de mejoras en las acciones de educación permanente. Consideraciones finales: esas dificultades pueden ser puestas en ecuación con la mejora de la gestión, sistematización de las actividades de educación permanente y definición de flujos de atención que posibiliten el diagnóstico precoz. Además del diagnóstico, es necesario establecer líneas de cuidado para personas viviendo con VIH y sida que tengan como inicio del proceso de asistencia a la salud las UBS.

Descriptores: Prestación de Atención de Salud; VIH; Sida; Atención Primaria de Salud; Enfermería. 


\section{INTRODUCTION}

Health Centers (HCs) are characterized by the individual and collective health care actions they offer to promote and protect health, prevent health complication, support diagnosis, treatment and rehabilitation. In this sense, they aim to develop integral care with impact on people's health situation and the autonomy and on health determinants of people collectively. These health care actions include, for instance, rapid HIV and syphilis tests, with pre- and post-test counseling ${ }^{(1-2)}$.

Basic care is considered the door to the Brazilian Unified Health System (UHS). In this perspective, the population's health monitoring, including follow-up, prevention and control of HIV infection and AIDS in an integral and resolving manner, is very pertinent. In addition, the diagnosis and follow-up of people living with HIV and AIDS (PLWHA), so far centralized, should be decentralized in specialized care services $(\mathrm{SCS})^{(3-5)}$.

The incentive to HIV testing has been considered one of the strategies to prevent the transmission of this disease and reduce morbidity and mortality. Testing enables early diagnosis, timely treatment start, and, with continued high adherence to the antiretroviral therapy, undetectable viral load and preserved TCD4 cell count. This care process will affect the quality of life of PLWHA, reduce morbidity, mortality and the incidence of HIV and AIDS infection ${ }^{(2-5)}$.

In addition, the use of rapid tests is associated with increased access to diagnosis of HIV infection, especially in more vulnerable population groups ${ }^{(3,5)}$. In the context of integral care to more vulnerable population groups, the access to the diagnosis of HIV and syphilis through rapid test should be promoted, and the treatment should start early. However, the implementation of rapid tests in basic care still presents a challenge to be overcome. Some of these issues are related to reduced number of professionals that are prepared to perform the rapid test and lack of products for service implementation and continuity ${ }^{(4-5)}$.

The implementation of a service that enables rapid tests and consequent development of care lines qualifies the basic care and provides a higher level of resolution and quality in care, besides allowing the restructuring and expansion of a care network for people living with HIV and AIDS, the development of activities of health education, reception, preventive actions and health care $^{(3,6)}$.

\section{OBJECTIVE}

Learn about the perception of health professionals who perform rapid tests in Health Centers (HCs) in Recife, Pernambuco.

\section{METHOD}

\section{Ethical aspects}

The study project was submitted and approved by the Ethics Committee for Research with Human Beings of Instituto de Medicina Integral Professor Fernando Figueira (Imip). The study was conducted following the requirements of Resolution $n^{\circ} 466$ of December 12, 2012(7) of the National Health Council. All participants were informed of the study and signed an informed consent form. To ensure confidentiality and anonymity, the participants were represented by numbers in this study.

\section{Theoretical and methodological references}

For data systematization and treatment, Bardin's content analysis $^{(8)}$ was used, in its thematic category. Data analysis was based on Waldow's theoretical reference ${ }^{(9)}$.

\section{Study scenario and type}

This is a descriptive and qualitative study conducted in nine HCs located in the health territory of Sanitary District VII, in Recife, Pernambuco.

\section{Methodological procedures}

For the study development, the units that performed rapid tests were initially selected and the interview was scheduled according to the availability of each professional. Then, the interview was conducted, collected data were analyzed, and finally the perceptions of the professionals performing rapid test were transcribed in full.

\section{Data source}

The study participants corresponded to nine nurses from the studied health units that performed rapid tests. Participant selection was intentional and the inclusion criteria were: professionals trained to perform the rapid test and who were performing the test for diagnosis of HIV infection in the HC. Nurses who were not performing the rapid test at the time of data collection were excluded.

\section{Data collection and organization}

Data were collected between May and October 2016, through individual interviews conducted by a researcher with experience in testing and care of people living with HIV/AIDS and who did not have any professional relationship with the HC. It was a semi-structured interview based on the following question: How is daily work perceived in the rapid test practice for HIV infection diagnosis?

\section{Data analysis}

The transcribed material was carefully read, seeking to identify words and groups of words that expressed the study meaning. These words were classified in categories of similarities according to the criteria of syntax or semantics. Based on the regularity of the speech and the presence of units of meaning, the statements were classified in two categories of analysis ${ }^{(8)}$ : "issues to perform rapid tests" and "opportunities for improvements in professional training and promotion of educational activities."

\section{RESULTS}

After data analysis, two categories were identified, related to the perception of the professionals in rapid test practice performed in the HCs located in Recife, Pernambuco: issues to perform rapid tests referring to the delivery of products, physical structure for testing and pre- and post-test counseling; and opportunities for improvements in professional training 
and promotion of educational activities referring to the need to systematize permanent education activities, with emphasis on pre- and post-test counseling and receipt of educational material to support educational activities.

Rapid tests are performed by nurses. One of the studied units performs testing only with pregnant women due to structural issues. Another unit performs rapid tests with people living outside its assigned area. For the interviewed professionals, the major issues related to performing rapid test are: delayed delivery of products; unavailability of personal protective equipment, in particular masks, goggles and aprons; and the test structure and physical area.

The major problems are related to the structure and physical area, which are not suitable to performing rapid tests and conducting post-test counseling. (E6)

The supply of products has flaws [...] there is no guarantee the products will be delivered [...] there is no printed forms to provide the result, it's improvised on prescription papers and other forms that are not intended for this purpose. (E1)

Training does not address aspects related to biosafety [...] there is no PPE to perform rapid tests. (E2)

There are no exclusive rooms to perform this service, and the physical areas are not compatible with the activity [...] I perform the rapid test when there is a room available; otherwise, I don't perform the test. (E3)

The professionals who perform rapid tests realize that advances in science related to the antiretroviral therapy (ART) and its proven effectiveness in the treatment of AIDS have promoted the provision of serological testing in health services. However, they highlight that the stigma associated with the disease is still present among the population and that health education actions related to HIV infection and AIDS are required.

The level of information about HIV and AIDS presented by the population is low [...] and the stigma remains strong in the population. (E6)

The professionals also report challenges when presenting the test result, in particular, the patient's feelings in case of a positive result.

There is technical responsibility and then we have to conduct the tests and give the result, but showing the results to the patient is a moment of distress. (E4)

The patients react with anxiety and sadness, it is necessary to be prepared for patient reception [...], it's not easy... (E7)

Permanent education is flawed, and it should be provided at the central level. (E8)

There is a lack of health education material, female condoms, signage, folders [...] components for health promotion and better information for the population about the prevention of sexually transmitted diseases and AIDS. (E9)
These challenges reflect on the test practice, generating distress when reporting the test result and in patient counseling before and after the test. Despite these issues, the professionals realize rapid tests of HIV and syphilis could be extended to areas not covered by the $\mathrm{HC}$.

Units that don't offer this service could offer it using an ondemand mechanism [...]; however, the supply of products has to be improved to make it happen. (E5)

\section{DISCUSSION}

The results of this study showed the challenges when performing rapid tests for HIV detection in the studied units. Investments are required to make these tests part of the routine of services offered in the HCs. The access to diagnosis has to be broadened, and studies show a high acceptance rate of testing in primary care. Then, the provision of this service in basic units contributes to easy access and higher number of tests performed ${ }^{(10-12)}$.

Despite the issues and the complexity of the factors involved in the actions related to rapid tests, the professionals in charge of rapid tests are expected to perform this activity in a perspective of care taking diversity into account, understanding the other as someone with rationality, cognition and feelings. In this perspective, rapid tests should go beyond a technique; the aspects involving rapid tests assume intensities and variations that are processed differently, depending on the context. Then, at the time of testing, a special care starts, which transformative for the patient ${ }^{(9)}$.

In the studied units, except for one $\mathrm{HC}$, the test is performed by nurses and only with pregnant women. The dissemination of rapid tests for HIV detection in the primary care network can contribute to infection control in general, and it is essential for the reduction of the vertical transmission, since the diagnosis in the preconception period or in the beginning of the pregnancy allows a better control of maternal infection and better results in the prophylaxis of vertical transmission of the virus ${ }^{(2,5)}$. However, in order to promote and facilitate the early diagnosis of HIV infection, the responsibility for testing should be of all health professionals working in the $\mathrm{HC}^{(12)}$.

This almost exclusive testing of pregnant women is due to the fact that the organization of actions to prevent HIV infection in the world began with a focus on vertical transmission, especially in pregnant women at risk, during the 1990s. Later, these actions assumed a universal character ${ }^{(2)}$. However, such coverage still needs to be expanded; a $21.3 \%$ rate of lack of diagnostic coverage of HIV infection at the time of delivery indicates the care team has to improve the reception of pregnant women during prenatal care ${ }^{(13-14)}$.

The need to maintain testing in pregnant women in basic care is unquestionable. However, it is extremely important to extend the access to diagnosis to other population groups besides pregnant women ${ }^{(13,15)}$. It should be considered that, even when performing tests in pregnant women only, challenges related to the distribution of supporting materials and the physical structure were also highlighted. A study conducted in the Southeast Region of Brazil showed that the infrastructure of the laboratory services should be improved so that tested persons could have timely access to test results ${ }^{(16)}$. 
In general, most factors that impact rapid tests are related to the supply of products, infrastructure, training, and test performed by all professionals of the unit. These issues happen at a universal level, in poor and rich countries. However, it is a scenario that may have intervention because the determinants, although multiple and complex, are known, and there are resources to change all aspects that create obstacles to the dissemination of rapid test for HIV detection ${ }^{(17-18)}$.

For the implementation of rapid test in primary care services, aspects related to the sensitization and qualification of the rapid test team should be observed, as well as having a proper physical area for the tests and available supplies, supporting material and access to the logistics system and laboratory products. It should be noted that all units should provide pre- and post-test guidance ${ }^{(4-5)}$.

The National Policy on Sexually Transmitted Diseases (STDs) and AIDS aims to reduce the incidence of HIV and other STDs by increasing the access to quality diagnosis, treatment and care. As part of the structuring to support PLWHA, in the 1990s, Specialized Care Services (SCS) were implemented for ambulatory care in Brazil. These services aim to ensure integral care through a multiprofessional team, offering prevention, promotion and access to antiretroviral therapy ${ }^{(2,5)}$.

Besides the diagnostic coverage, the Ministry of Health recommends the control of HIV infection in basic care units for easy access of PLWHA to health services, for continuous care and qualified treatment. Then, the patient risk should be stratified, that is, those considered asymptomatic should receive continuous attention in the primary care network, while the care of symptomatic, co-infected people, pregnant and children can be shared with the $\mathrm{SCS}^{(5,19)}$.

Several factors may impact the diagnosis and care of PLWHA in basic care. This study also presented aspects related to the population's stigma regarding the disease, despite advances in the diagnosis and management of PLWHA, as well as improvements in the provision of instruments and didactic support material for health education actions related to HIV infection and AIDS. There are still many barriers to be pulled down, such as fear and prejudice in relation to AIDS, which remain strong, despite the available knowledge on the subject. Prejudice attributes negative moral values to people with the disease; the stigma depersonalizes and de-characterizes the individual, making it difficult to extend the diagnosis and decentralize care in primary attention ${ }^{(20-21)}$.

Another aspect observed in this study refers to the challenges reported by the interviewees in post-test counseling, especially when the result is positive. The impact of this diagnosis is usually intense for both the individual and the professional. Therefore, the professional should be prepared to offer emotional support, respecting the patient's timing and reaction to the result. This study observed that the interviewees still do not feel secure for conducting rapid tests, nor in post-test counseling with positive results. This aspect can be resolved with the implementation of local projects of permanent education ${ }^{(22)}$.

Counseling is a essential step in the testing process. In the post-test period, the professional should provide proper emotional support and seek to establish a connection of trust. Then, the patients will feel more confident and explain their risk practices, and the professional will have the opportunity to make more effective interventions. In addition, in cases of diagnosis of HIV infection, the professional should offer emotional support to the patients to help them deal with this new condition and encourage their active participation in the therapeutic process.

A study conducted in Porto Alegre observed that primary care professionals considered counseling as the most complex action of testing. The interviewees also mentioned the feeling of frustration in terms of counseling in the units ${ }^{(22)}$. However, regardless of the test result, the professional should be able to perform a proper approach. In all situations counseling is an important step in educational actions of reception and clarification. However, studies show that health professionals need to be trained, even in service, for counseling and clinical management actions ${ }^{(16,22)}$.

In this sense, the person who performs rapid tests and provides counseling should have updated knowledge, with periodic update on STD, HIV and AIDS, to value what the patient knows, thinks and feels at the moment of the diagnosis result. Qualification of professionals who work in HCs should be ensured through face-to-face and distance training; in addition, professionals should be supported by colleagues with more experience in issues related to HIV infection and AIDS ${ }^{(19,22-23)}$.

These aspects represent challenges for the implementation and consolidation of rapid tests in basic health care. A study that evaluated HIV testing during prenatal care and delivery in the UHS showed the need to strengthen public policies for actions for HIV transmission control and qualify primary care to expand the use of rapid tests, and offer at the family health units the exams of TCD4 lymphocyte counts, viral load and access to antiretroviral therapy ${ }^{(5,16,19)}$.

\section{Study limitations}

The authors consider this study may present limitations related to challenges for understanding the reality reported by the nurses, considering the possibility of evaluators feeling distant from the reality described by the study participants. Other aspects refer to the representativeness of individual statements in relation to a larger group, due to the reduced number of participants.

\section{Contributions to nursing, health care or public policies}

The study may provide elements for the situational diagnosis, considering the performance of rapid tests in HCs and then offer elements to improve or adjust the supply of products, and plan training and care management. This way, it is possible to create care lines for HIV/AIDS diagnosis through rapid tests and set hierarchical and integral care flow in the basic care network, even considering that the working conditions of health professionals in the UHS many times have created obstacles for the development of practices committed to social transformation ${ }^{(24)}$ and care quality.

\section{FINAL CONSIDERATIONS}

The studied health units still present challenges related to the delivery of products, physical structure to perform rapid tests and pre- and post-test counseling. These challenges can be solved with systematic planning of order and supply of products and improvements in the infrastructure. 
The required training and motivation of the professionals that perform the tests can be solved with systematization of permanent education activities, implementation of mentoring, supervised activities and problematized and planned abilities after the identification of learning gaps. For example, the provision of instruments for post-test counseling and biosafety aspects regarding test performance, as well as qualification of all professionals in the team; thus creating a network of interaction and collaboration among professionals, enabling to share knowledge when conducting the tests, counseling activities and educational activities.

\section{REFERENCES}

1. Brasil. Ministério da Saúde. Portaria n 2.488, de 21 de outubro de 2011. Aprova a Política Nacional de Atenção Básica, estabelecendo a revisão de diretrizes e normas para a organização da Atenção Básica, para a Estratégia Saúde da Família (ESF) e o Programa de Agentes Comunitários de Saúde (PACS). Diário Oficial da União [Internet]. Brasília (DF); 24 out. 2011 [cited 2017 Dec 10]. Seção I, p. 48. Available from: http://www.saude.mt.gov.br/upload/legislacao/2488-\%5B5046-041111-SES-MT\%5D.pdf

2. Kellerman SE, Ahmed S, Feeley-Summerl T, Jay J, Kim MH, Koumans E, et al. Beyond PMTCT: Keeping HIV exposed and positive children healthy and alive. AIDS [Internet]. 2013 [cited 2016 Jul 1];27(2):S225-S233. Available from: https://www.ncbi.nlm.nih.gov/ pmc/articles/PMC4087192/

3. Brasil. Ministério da Saúde. Orientações para implantação dos testes rápidos de HIV e sífilis na atenção básica: Rede Cegonha [Internet]. Brasília (DF): Ministério da Saúde; 2013 [cited 2017 Dec 7]. Available from: http://189.28.128.100/dab/docs/portaldab/ publicacoes/orientacoes_implantacao_testes_rapidos_hiv_sifilis.pdf

4. Brasil. Ministério da Saúde. Transmissão vertical do HIV e sífilis: estratégias para redução e eliminação [Internet]. Brasília (DF); 2014[cited 2017 Dec 10]. Available from: https://prevencaodstaidshvtb.files.wordpress.com/2014/12/folder_transmissao_vertical_ hiv_sifilis_web_pd_60085.pdf

5. Brasil. Ministério da Saúde. 5 passos para implementação do manejo da infecção pelo HIV na Atenção Básica: guia para gestores [Internet]. Brasília (DF): Ministério da Saúde; 2015 [cited 2017 Dec 7]. Available from: http://www.aids.gov.br/pt-br/ pub/2014/5-passos-para-implementacao-do-manejo-da-infeccao-pelo-hiv-na-atencao-basica

6. Barreto ML, Teixeira MG, Bastos FI, Ximenes RA, Barata RB, Rodrigues LC. Successes and failures in the control of infectious diseases in Brazil: social and environmental context, policies, interventions, and research needs. Lancet [Internet]. 2011 [cited 2016 Jul 1];377(9780):1877-89. Available from: http://www.thelancet.com/pdfs/journals/lancet/PIIS0140-6736(11)60202-X.pdf

7. Brasil. Ministério da Saúde. Conselho Nacional de Saúde. Resolução no 466, de 12 de dezembro de 2012. Aprova as diretrizes e normas regulamentadoras de pesquisas envolvendo seres humanos [Internet]. Diário Oficial da União. Brasília, n. 12, p. 59, 13 jun 2013 [cited 2017 Nov 20]. Seção 1. Available from: http://bvsms.saude.gov.br/bvs/saudelegis/cns/2013/res0466_12_12_2012.html

8. Bardin L. Análise de conteúdo. Lisboa: Edições 70, 2011.

9. Waldow VR. Cuidar: expressão humanizadora da enfermagem. Rio de Janeiro: Vozes; 2006.

10. Martín-Cabo R, Losa-García JE, Iglesias-Franco H, Iglesias-González R, Fajardo-Alcántara A, Jiménez-Moreno A. Promoción de la detección del virus de la inmunodeficiencia humana en atención primaria. Gac Sanit[Internet]. 2012 [cited 2016 Jul 1];26(2):116-22. Available from: http://scielo.isciii.es/scielo.php?script=sci_arttext\&pid=S0213-91112012000200005

11. Torres RCP, Taberné CA, Torres LAP, Espejo JE, Fernández CC, Galiana LF. Aceptabilidad de la búsqueda oportunista de la infección por el virus de la inmunodeficiencia humana mediante serología en pacientes captados en centros de atención primaria de España: estudio VIH-AP. Aten Primaria [Internet]. 2015 [cited 2016 Jul 1];48(6):383-93. Available from: http://www.elsevier.es/ es-revista-atencion-primaria-27-articulo-aceptabilidad-busqueda-oportunista-infeccion-por-S0212656715002620

12. Phanuphak P, Lo YR. Implementing early diagnosis and treatment: programmatic considerations. Curr Opin HIV AIDS [Internet]. 2015 [cited 2016 Jul 1];10(1):69-75. Available from: http://journals.Iww.com/co-hivandaids/Fulltext/2015/01000/Implementing_early_ diagnosis_and_treatment_.12.aspx

13. Domingues RM, Szwarcwald CL, Souza PR Jr, Leal MC. Prenatal testing and prevalence of HIV infection during pregnancy: data from the "Birth in Brazil" study, a national hospital-based study. BMC Infect Dis [Internet]. 2015 [cited 2016 Jul 1];15:100. Available from: https://www.ncbi.nlm.nih.gov/pmc/articles/PMC4346116/

14. Menezes LSH, Palácios VRCM, Alcântara MSV, Bichara CNC. Prevalência da infecção por HIV em grávidas no Norte do Brasil. DST J Bras Doenças Sex Transm[Internet]. 2012 [cited 2016 Jul 1];24(4):250-54. Available from: http://www.dst.uff.br/revista24-4-2012/6Prevalencia $\% 20 \mathrm{da} \% 20 \mathrm{Infeccao} \% 20$ por $\% 20 \mathrm{HIV} \% 20 \mathrm{em} \% 20 \mathrm{Gravidas.pdf}$

15. Silva ITS, Valenca CN, Silva RAR. Mapping the implementation of the rapid HIV test in the Family Health Strategy: the nurses' perspective. Esc Anna Nery Rev Enferm[Internet]. 2017[cited 2017 Oct 9];21(4):e20170019. Available from: http://www.scielo.br/pdf/ ean/v21n4/1414-8145-ean-2177-9465-EAN-2017-0019.pdf

16. Gomes DM, Oliveira MIC, Fonseca SC. Avaliação da testagem anti-HIV no pré-natal e na assistência ao parto no Rio de Janeiro, Brasil. Rev Bras Saúde Mater Infant[Internet]. 2015 [cited 2016 Jul 1];15(4):413-23. Available from: http://www.scielo.br/pdf/rbsmi/ v15n4/1519-3829-rbsmi-15-04-0413.pdf 
17. Araújo CLF, Aguiar PS, Santos GKA, Oliveira MGP, Câmara LS. A testagem anti-HIV nos serviços de ginecologia do município do Rio de Janeiro. Esc Anna Nery Rev Enferm[Internet]. 2014[cited 2017 Oct 16];18(1):82-9. Available from: http://www.scielo.br/pdf/ean/ v18n1/1414-8145-ean-18-01-0082.pdf

18. Zambenedetti G, Silva RAN. Descentralização da atenção em HIV-Aids para a atenção básica: tensões e potencialidades. Physis [Internet]. 2016 [cited 2016 Jul 1];26(3):785-806. Available from: http://www.scielo.br/pdf/physis/v26n3/0103-7331-physis-26-03-00785.pdf

19. Brasil. Ministério da Saúde. Secretaria de Vigilância em Saúde. Departamento de DST, Aids e Hepatites Virais. Protocolo clínico e diretrizes terapêuticas para atenção integral às pessoas com infecções sexualmente transmissíveis [Internet]. Brasília: Ministério da Saúde; 2015[cited 2017 Dec 10]. Available from: http://www.aids.gov.br/sites/default/files/anexos/publicacao/2015/58357/miolo pcdt_ist_15_08_pdf_22990.pdf

20. Porto TSAR, Silva CM, Vargens OMC. Caring for women with HIV/AIDS: an interactionist analysis from the perspective of female healthcare professionals. Rev Gaúcha de Enferm[Internet]. 2014 [cited 2016 Jul 1];35(2):40-6. Available from: http://www.scielo.br/ $\mathrm{pdf} /$ rgenf/v35n2/1983-1447-rgenf-35-02-00040.pdf

21. Agustí C, Fernández L, Mascort J, Carrillo R, Casabona J. Barreras para el diagnóstico de las infecciones de transmisión sexual y virus de la inmunodeficiencia humana en Atención Primaria en España. Enferm Infecc Microbiol Clin[Internet]. 2013 [cited 2016 Jul 1];31:451-54. http://www.elsevier.es/es-revista-enfermedades-infecciosas-microbiologia-clinica-28-articulo-barreras-el-diagnostico-lasinfecciones-S0213005X13000037

22. Rocha KB, Santos RRG, Conz J, Silveira ACT. Network transversality: matrix support in the decentralization of counseling and rapid testing for HIV, syphilis and hepatitis. Saúde Debate [Internet]. 2016 [cited 2016 Jul 1];40(109):22-33. Available from: http://www. scielo.br/pdf/sdeb/v40n109/en_0103-1104-sdeb-40-109-00022.pdf

23. Marques SC, Tyrrell, MAR, Oliveira DC. Educational practices for HIV/aids prevention among users of the basic healthcare system in Rio de Janeiro/Brazil. Rev Min Enferm[Internet]. 2013 [cited 2016 Jul 1];17(3):538-46. Available from: http://www.reme.org.br/artigo/ detalhes/671

24. Santos FPA, Acioli S, Rodrigues VP, Machado JC, Souza MS, Couto TA. Nurse care practices in the Family Health Strategy. Rev Bras Enferm [Internet]. 2016 [cited 2016 Jul 1];69(6):1060-7. Available from: http://www.scielo.br/pdf/reben/v69n6/en_0034-7167reben-69-06-1124.pdf 